UDC $575.1+577.11+577.21$

\title{
Association of the leukemia inhibitory factor gene polymorphism rs929271 with idiopathic mild intellectual disability
}

\author{
R. V. Gulkovskyi ${ }^{1,2}$, L. S. Volkova ${ }^{1,2}$, L. A. Livshits ${ }^{1,2}$ \\ ${ }^{1}$ Institute of Molecular Biology and Genetics, NAS of Ukraine \\ 150, Akademika Zabolotnoho Str., Kyiv, Ukraine, 03680 \\ 2 Educational and Scientific Center «Institute of Biology», \\ Taras Shevchenko National University of Kyiv \\ 64/13, Volodymyrska Str., Kyiv, Ukraine, 01601 \\ livshits@imbg.org.ua
}

\begin{abstract}
Aim. To investigate the possible association of LIF gene polymorphism rs929271 with mild intellectual disability (ID). Methods. The group of patients with mild (IQ score between 50 and 70) idiopathic intellectual disability consisted of 64 individuals including $40(62.5 \%)$ males and 24 (47.5\%) females. The control group consisted of 238 healthy volunteers from different regions of Ukraine. Polymorphic variants of LIF gene rs929271 were detected using PCR followed by Hinf1 RFLP analysis. Results. The data concerning LIF genotypes and allelic variants distribution in ID patients and control group were obtained. Statistical analysis shows significant differences at rs929271 for both genotype and allele frequency when comparing ID cases and controls $(\mathrm{p}=0.01$ and 0.02 , respectively). Conclusions. Our results suggest that LIF gene polymorphism rs929271 is associated with idiopathic mild intellectual disability. Therefore, we propose LIF as a new marker of genetic susceptibility for intellectual disability.
\end{abstract}

Ke y word s: LIF gene, intellectual disability, polymorphism, population.

\section{Introduction}

Intellectual disability is a neurodevelopmental disorder, affecting about $3 \%$ of the population, and is associated with a series of social and medical handicaps [1]. The causes of intellectual disability vary with the severity of the condition: moderate-to-severe intellectual disability (IQ less than 50) is much more likely to be due to a single pathological cause (genetic or environmental) whereas mild ID (defined as an IQ score between 50 and 70) is rather due to the complex condition in origin [2].

Leukemia inhibitory factor (LIF) is a member of the neuropoietic family of neurotrophins and was found to regulate the neuronal phenotype and coordinates astrocyte, oligodendrocyte, microglia, and inflammatory cell responses [3-5]. Furthermore, LIF is shown to act as a survival factor for neurons and oligodendrocytes $[6,7]$.

Upon binding to the heterodimeric glycoprotein 130 (gp130)/LIF receptor (LIFR) complex, LIF activates several major intracellular signaling pathways including ERK/MAPK signaling [8,9]. It was discovered that ERK/MAPK pathway is important for normal cognitive development and is required for certain types of synaptic plasticity $[10,11]$. It was shown that the mutations in genes coding for ERK/ MAPK pathway proteins and regulators such as SYNGAP1 and RPS6KA3 cause non-syndromic intellectual disability (NS-ID) and autism spectrum disorders [12-16].

The leukemia inhibitory factor gene is located on chromosome 22q12.1-q12.2 [17]. The T to G transversion rs 929271 is located in the 3 primed untrans-

(C) 2015 R. V. Gulkovskyi et al.; Published by the Institute of Molecular Biology and Genetics, NAS of Ukraine on behalf of Biopolymers and Cell. This is an Open Access article distributed under the terms of the Creative Commons Attribution License (http://creativecommons.org/licenses/by/4.0/), which permits unrestricted reuse, distribution, and reproduction in any medium, provided the original work is properly cited 
lated region of the LIF gene. This polymorphism is suggested to reduce mRNA stability and finally may have an effect on the amount of secreted LIF [18]. Previous reports have demonstrated that the LIF gene variant (rs929271) may produce susceptibility to vascular dementia, hebephrenic schizophrenia and deterioration of working memory function $[19,20]$.

Aim of this study is to evaluate the possible association of the LIF gene polymorphism rs929271 with mild intellectual disability.

\section{Materials and Methods}

DNA-samples were extracted from peripheral blood leucocytes of unrelated volunteers from different regions of Ukraine and ID patients by the standard phenol-chloroform method. Informed consents were obtained from all the individuals participating in our study.

The group of patients with mild (IQ score between 50 and 70) idiopathic intellectual disability consisted of 64 individuals including 40 (62.5\%) males and 24 $(47.5 \%)$ females, where previous extensive genetic investigations have revealed no abnormalities. All patients underwent physical and neurological examination (test used for IQ: WISC III, WISC-R, WISC) and standard G-banding karyotype analysis. DNA tests to determine Fragile X status (FRAXA, FRAXE, FRAXF loci) and Prader Willi/Angelman syndromes (PW/ AS) were performed to rule out the known genetic causes of ID prior to further investigation. Array-CGH analysis (400K resolution) revealed no any pathological rearrangements in all patients.

The control group consisted of 238 individuals including $128(53.8 \%)$ males and 110 (46.2\%) females. This group may be considered representative for the estimation of DNA polymorphism frequency in autosomal genes [21, 22].

The presence of LIF polymorphism rs929271 was examined by PCR-RFLP (restriction fragment length polymorphism) analysis. Specific oligonucleotides, designed and synthesized in accordance to corresponding sequences of LIF gene, were used as primers: forward: 5'-GGGGACACAGAAACAAG GACAGGG -3' and reverse: 5'-AAGGGTCGGAT CTGAGAGAATGGG-3'. Primers were designed us-

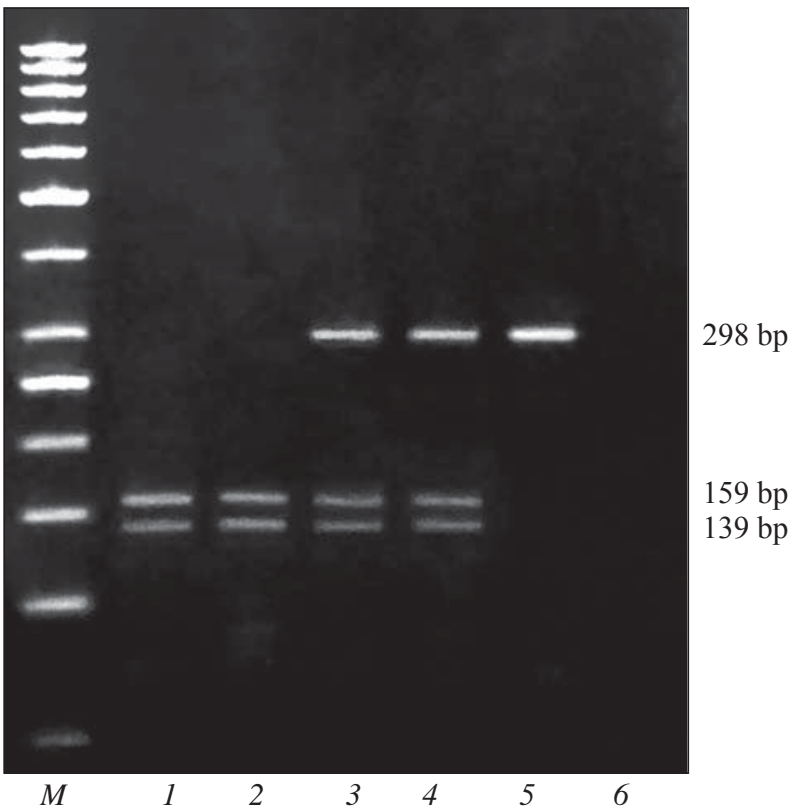

Fig. 1. RFLP analysis of rs 929271 LIF gene variant (2 \% agarose gel electrophoresis): $M$ - molecular mass marker (Ladder 50 bp); 1, 2, - individuals with homozygous genotype TT; 3, 4 individuals with heterozygous genotype TG; 5 - individual with homozygous genotype GG, 6 - negative control

ing a web-based PRIMER 3.0 program (http://workbench.sdsc.edu). We used the «BLAST» program at http://www.ncbi.nlm.nih. gov/blast to check for the specificity of the primers. Hypothetical RFLP results

Table 1. Distribution of genotypes

and allele variants in investigated groups

\begin{tabular}{|c|c|c|}
\hline & $\begin{array}{c}\text { Control group, } \\
n=238\end{array}$ & $\begin{array}{c}\text { ID patients, } \\
n=64\end{array}$ \\
\hline \multicolumn{3}{|c|}{ Genotype, $n(\%)$} \\
TT & $107(45)$ & $18(28.1)$ \\
TG & $106(44.5)$ & $35(54.7)$ \\
GG & $25(10.5)$ & $11(17.2)$ \\
TG+GG & $131(55)$ & $46(71.9)^{*}$ \\
& Allele, $n($ frequency) \\
T & $320(0.672)$ & $71(0.555)$ \\
G & $156(0.328)$ & $57(0.445)^{*}$ \\
\hline
\end{tabular}

Note. $\mathrm{N}$ - number of individuals; * statistically reliable difference $(\mathrm{P}<0,05)$. 
were tested using NEB cutter V2.0 (http://tools.neb. com/NEBcutter2).

The PCR amplification was performed in a final volume of $25 \mu$ l containing $1 \times$ PCR buffer, $1.5 \mathrm{mM}$ $\mathrm{MgCl} 2,200 \mu \mathrm{M}$ of each dNTP, $1 \mu \mathrm{M}$ of each primer, 0.2 units of Taq-DNA polymerase and $200 \mathrm{ng}$ of the DNA template. The cycling conditions were as follows: initial denaturation at $95{ }^{\circ} \mathrm{C}$ for $5 \mathrm{~min}, 30 \mathrm{cy}$ cles consisting of denaturation at $94{ }^{\circ} \mathrm{C}$ for $30 \mathrm{~s}$, annealing at $63{ }^{\circ} \mathrm{C}$ for $30 \mathrm{~s}$, extension at $72{ }^{\circ} \mathrm{C}$ for 30 $\mathrm{s}$ and a final elongation step at $72{ }^{\circ} \mathrm{C}$ for $3 \mathrm{~min}$. The amplified fragments were digested with HinfI. Digestion was performed in $15 \mu 1$ reaction volume containing $1 \mathrm{X}$ reaction buffer, 0.5 units of the restriction enzyme and $10 \mu \mathrm{l}$ of purified PCR product, incubated at $37{ }^{\circ} \mathrm{C}$ overnight and analyzed in $2 \%$ standard agarose electrophoresis.

The results were statistically assessed using OpenEpi software and Fisher's 2 by 2 exact test, as well as odd ratio (OR) calculation; $\mathrm{p}<0.05$ was considered to be statistically significant test [23].

\section{Results and Discussion}

The designed primers successfully amplified the corresponding fragment (298 bp) of the LIF gene. The $\mathrm{T}$ to $\mathrm{G}$ transition in rs929271 variant removes a restriction site for endonuclease HinfI. Thereby three different patterns could be observed for the rs 929271 variant after the restriction digestion: a $298 \mathrm{bp}$ band (for rs929271 T/T); a 298 bp, a 159 bp and a 139 bp bands (for rs929271 T/G); a $159 \mathrm{bp}$ and a $139 \mathrm{bp}$ bands (rs929271 G/G) (Fig. 1).

Based on the RFLP analysis of the rs929271 variant, the individuals were classified into three groups: TT, TG and GG. Genotypes and allele frequencies of the rs929271 polymorphism are presented in Table 1. The observed genotype distributions showed no deviations from Hardy-Weinberg expectations in general population of Ukraine and in ID patients group.

It was determined that total frequency of heteroand homozygous carriers of the LIF gene rs929271 minor allele, in this case that of guanine $(\mathrm{G})$, is reliably higher $(p=0.01)$ in the ID patients group $(71.9 \%)$ compared to the control group (55\%). The minor G-allele occurred less frequently in the control gro- up -0.328 than in the ID patients group $-0.445(\mathrm{p}=$ $=0.02$ ). It was shown that the risk of mild ID development increased for both hetero- and homozygous carriers of minor rs929271 G-allele and the odd ratio was 2.09 (95\% CI: 1.14-3.81).

Our results suggest that the LIF gene polymorphism rs929271 is associated with idiopathic mild intellectual disability. These data can be explained by a decrease of LIF levels in the LIF gene rs929271 minor allele $G$ carriers that in turn, may affect the regulation of neurogenesis and neuroprotection at least via LIF/ERK/MAPK signaling.

Therefore, we propose $L I F$ as a new marker of genetic susceptibility for intellectual disability. Future investigations are necessary to explain the molecular mechanisms of the LIF involvement in ID pathogenesis.

\section{Acknowledgements}

We thank the patients and volunteers for their cooperation.

\section{REFERENCES}

1. Leonard $H$, Wen $X$. The epidemiology of mental retardation: challenges and opportunities in the new millennium. Ment Retard Dev Disabil Res Rev. 2002;8(3):117-34.

2. Flint J. Genetic basis of cognitive disability. Dialogues Clin Neurosci. 2001;3(1):37-46.

3. Holmberg $K H$, Patterson $P H$. Leukemia inhibitory factor is a key regulator of astrocytic, microglial and neuronal responses in a low-dose pilocarpine injury model. Brain Res. 2006;1075(1):26-35.

4. Kerr BJ, Patterson $P H$. Leukemia inhibitory factor promotes oligodendrocyte survival after spinal cord injury. Glia. 2005;51(1):73-9.

5. Sugiura $S$, Lahav $R$, Han J, et al. Leukaemia inhibitory factor is required for normal inflammatory responses to injury in the peripheral and central nervous systems in vivo and is chemotactic for macrophages in vitro. Eur J Neurosci. 2000; 12(2):457-66.

6. Barres BA, Schmid R, Sendnter M, Raff MC. Multiple extracellular signals are required for long-term oligodendrocyte survival. Development. 1993;118(1):283-95.

7. Martinou JC, Martinou I, Kato AC. Cholinergic differentiation factor (CDF/LIF) promotes survival of isolated rat embryonic motoneurons in vitro. Neuron. 1992;8(4): $737-$ 44.

8. Niwa H, Ogawa K, Shimosato D, Adachi K. A parallel circuit of LIF signalling pathways maintains pluripotency of mouse ES cells. Nature. 2009;460(7251):118-22. 
Association of the leukemia inhibitory factor gene polymorphism rs929271 with idiopathic mild intellectual disability

9. Hirai H, Karian P, Kikyo N. Regulation of embryonic stem cell self-renewal and pluripotency by leukaemia inhibitory factor. Biochem J. 2011;438(1):11-23.

10. Zhu JJ, Qin Y, Zhao M, Van Aelst L, Malinow R. Ras and Rap control AMPA receptor trafficking during synaptic plasticity. Cell. 2002;110(4):443-55.

11. Thomas GM, Huganir RL. MAPK cascade signalling and synaptic plasticity. Nat Rev Neurosci. 2004;5(3):173-83.

12. Hamdan FF, Gauthier J, Spiegelman D, et al. Mutations in SYNGAP1 in autosomal nonsyndromic mental retardation. N Engl J Med. 2009;360(6):599-605.

13. Hamdan FF, Daoud H, Piton A, et al. De novo SYNGAP1 mutations in nonsyndromic intellectual disability and autism. Biol Psychiatry. 2011;69(9):898-901.

14. Krepischi AC, Rosenberg C, Costa SS, Crolla JA, Huang S, Vianna-Morgante AM. A novel de novo microdeletion spanning the SYNGAP1 gene on the short arm of chromosome 6 associated with mental retardation. Am J Med Genet A. 2010;152A(9):2376-8.

15. Delaunoy JP, Dubos A, Marques Pereira P, Hanauer A. Identification of novel mutations in the RSK2 gene (RPS6KA3) in patients with Coffin-Lowry syndrome. Clin Genet. 2006; 70(2):161-6.

16. Field M, Tarpey P, Boyle J, et al. Mutations in the RSK2 (RPS6KA3) gene cause Coffin-Lowry syndrome and nonsyndromic X-linked mental retardation. Clin Genet. 2006; 70(6):509-15.

17. Sutherland GR, Baker E, Hyland VJ, Callen DF, Stahl J, Gough NM. The gene for human leukemia inhibitory factor (LIF) maps to 22q12. Leukemia. 1989;3(1):9-13.

18. Ishida $R$, Ezura $Y$, Iwasaki $H$, et al. Linkage disequilibrium and haplotype analysis among four novel single-nucleotide polymorphisms in the human leukemia inhibitory factor (LIF) gene. J Hum Genet. 2001;46(10):557-9.

19. Okahisa Y, Ujike H, Kunugi $H$, et al. Leukemia inhibitory factor gene is associated with schizophrenia and working memory function. Prog Neuropsychopharmacol Biol Psychiatry. 2010;34(1):172-6.

20. Kim Y, Park J, Lee C. Multilocus genotypic association with vascular dementia by multifactor dimensionality reduction and entropy-based estimation. Psychiatr Genet. 2009;19(5): 253-8.

21. Cordell HJ, Clayton DG. Genetic association studies. Lancet. 2005;366(9491):1121-31.

22. Balding DJ. A tutorial on statistical methods for population association studies. Nat Rev Genet. 2006;7(10):781-91.

23. Sullivan KM, Dean A, Soe MM. OpenEpi: a web-based epidemiologic and statistical calculator for public health. Public Health Rep. 2009;124(3):471-4.
Р. В. Гулковський, Л. С. Волкова, Л. А. Лівшиць

Асоціація поліморфізму rs929271 гена лейкемія-інгібуючого фактора 3 ідіопатичною легкою інтелектуальною недісздатністю

Мета. Дослідити можливу асоціацію поліморфізму rs929271 гена LIF з легкою інтелектуальною недієздатністю (IH). Методи. Група паціснтів з легкою (IQ між 50 і 70) ідіопатичною інтелектуальною недієздатністю складалася 364 індивідів, включаючи 40 (62,5 \%) чоловіків і 24 (47,5\%) жінки. Контрольна група складалася 3238 здорових добровольців з різних регіонів України. Поліморфні варіанти rs929271 гена LIF виявляли за допомогою ПЛР з подальшим Hinf1 ПДРФ аналізом. Результати. Були отримані дані про розподіл генотипів і алельних варіантів гена LIF в групі пацієнтів з IH і в контрольній групі. Статистичний аналіз показує значимі відмінності по rs929271 як для частот генотипів, так і алельних варіантів при порівнянні досліджуваної та контрольної груп ( $p=0,01$ і 0,02, відповідно). Висновки. Наші результати показують, що поліморфізм rs929271гена LIF асоційований з легкою ідіопатичною інтелектуальною недієздатністю. Тому ми пропонуємо LIF в якості нового маркера генетичної схильності до інтелектуальної недієздатності.

Кл юч ов і сл ов а: ген LIF, інтелектуальна недієздатність, поліморфізм, популяція.

\section{Р. В. Гулковский, Л. С. Волкова, Л. А. Лившиц}

Ассоциация полиморфизма rs929271 гена лейкемия-ингибирующего фактора с идиопатической легкой интеллектуальной недееспособностью

Цель. Исследовать возможную ассоциацию полиморфизма rs929271 гена LIF с легкой интеллектуальной недееспособностью (ИН). Методы. Группа пациентов с легкой (IQ между 50 и 70) идиопатической интеллектуальной недееспособностью состояла из 64 индивидов, включая 40 (62,5\%) мужчин и $24(47,5 \%)$ женщины. Контрольная группа состояла из 238 здоровых добровольцев из разных регионов Украины. Полиморфные варианты rs929271 гена LIF выявляли посредством ПЦР с последующим Hinf1 ПДРФ анализом. Результаты. Были получены данные о распределении генотипов и аллельных вариантов гена LIF в группе пациентов с ИН и в контрольной группе. Статистический анализ показывает значимые различия по rs929271 как для частот генотипов, так и аллелей при сравнении исследуемой и контрольной групп ( $p=0,01$ и 0,02 , соответственно). Выводы. Наши результаты показывают, что полиморфизм rs929271гена LIF ассоциирован с легкой идиопатической интеллектуальной недееспособностью. Поэтому мы предлагаем LIF в качестве нового маркера генетической предрасположенности к интеллектуальной недееспособности.

Кл юч е в ы е сл ов а: ген LIF, интеллектуальная недееспособность, полиморфизм, популяция.

Received 10.01.2015 